\title{
CD49d is a disease progression biomarker and a potential target for immunotherapy in Duchenne muscular dystrophy
}

Fernanda Pinto-Mariz ${ }^{1,2,3}$, Luciana Rodrigues Carvalho ${ }^{1}$, Alexandra Prufer De Queiroz Campos Araujo², Wallace De Mello', Márcia Gonçalves Ribeiro², Maria Do Carmo Soares Alves Cunha², Pedro Hernan Cabello ${ }^{6}$, Ingo Riederer ${ }^{1}$, Elisa Negroni ${ }^{3}$, Isabelle Desguerre ${ }^{5}$, Mariana Veras' ${ }^{1}$, Erica Yada ${ }^{3}$, Yves Allenbach $^{6}$, Olivier Benveniste ${ }^{6}$, Thomas Voit ${ }^{3}$, Vincent Mouly ${ }^{3}$, Suse Dayse Silva-Barbosa ${ }^{1,7}$, Gillian Butler-Browne ${ }^{3^{*}}$ and Wilson Savino ${ }^{1 *}$

\begin{abstract}
Background: Duchenne muscular dystrophy (DMD) is caused by mutations in the dystrophin gene. The immune inflammatory response also contributes to disease progression in DMD patients. In a previous study, we demonstrated higher levels of circulating CD49dhi and CD49ehi T cells in DMD patients compared to healthy control. DMD patients are clinically heterogeneous and the functional defect cannot be correlated with genotype. Therefore, it is important to be able to define reliable noninvasive biomarkers to better define the disease progression at the beginning of clinical trials.
\end{abstract}

Results: We studied 75 DMD patients at different stages of their disease and observed that increased percentages of circulating $C D 4^{+} C D 49 d^{\text {hi }}$ and $C D 8^{+} C D 49 d^{\text {hi }} T$ lymphocytes were correlated with both severity and a more rapid progression of the disease. Moreover, $\mathrm{T}^{+} \mathrm{CD} 49 \mathrm{~d}^{+}$cells were also found in muscular inflammatory infiltrates.

Functionally, T cells from severely affected patients exhibited higher transendothelial and fibronectin-driven migratory responses and increased adhesion to myotubes, when compared to control individuals. These responses could be blocked with an anti-CD49d monoclonal antibody.

Conclusion: CD49d can be used as a novel biomarker to stratify DMD patients by predicting disease progression for clinical trials. Moreover, anti-CD49d peptides or antibodies can be used as a therapeutic approach to decrease inflammation-mediated tissue damage in DMD.

Keywords: Duchenne muscular dystrophy, Inflammation, CD49d, T lymphocytes, Predictive biomarker, Immunotherapy

\section{Background}

Duchenne muscular dystrophy (DMD) is the most common genetic muscular dystrophy, affecting 1 in 5000 male births. It is caused by mutations in the dystrophin gene, leading to functional loss or absence

\footnotetext{
*Correspondence: gillian.butler-browne@upmc.fr; savino.w@gmail.com Suse Dayse Silva-Barbosa, Gillian Butler-Browne, and Wilson Savino share the seniorship of the manuscript.

${ }^{3}$ Sorbonne Universités, UPMC Univ Paris 06, UM76, INSERM U974, CNRS FRE3617, Center for Research in Myology, 47 boulevard de l'Hopital, Paris 75651, France

'Laboratory on Thymus Research, Oswaldo Cruz Foundation, Rio de Janeiro, Brazil
} Full list of author information is available at the end of the article of the protein $[1,2]$. The results of a recent phase 3 clinical trial using exon-skipping strategies failed to show significant functional improvement $[3,4]$ probably due to the clinical heterogeneity of the patients that is a hallmark of the disease [5]. This emphasizes the urgent need to define reliable noninvasive biomarkers to better define these patient populations at the beginning of the trial and monitor the results of corrective strategies.

It is known that in DMD, there is an inflammatory process following muscular necrosis, which leads to fibrotic remodeling [6]. In this context, it has been

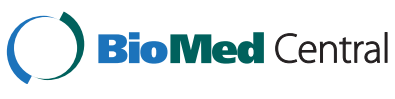

(c) 2015 Pinto-Mariz et al. Open Access This article is distributed under the terms of the Creative Commons Attribution 4.0 International License (http://creativecommons.org/licenses/by/4.0/), which permits unrestricted use, distribution, and reproduction in any medium, provided you give appropriate credit to the original author(s) and the source, provide a link to the Creative Commons license, and indicate if changes were made. The Creative Commons Public Domain Dedication waiver (http://creativecommons.org/publicdomain/zero/1.0/) applies to the data made available in this article, unless otherwise stated. 
demonstrated that there is a correlation between the absence of $\mathrm{B}$ and $\mathrm{T}$ lymphocytes and a decrease in fibrosis in the SCID/mdx mouse [7]. Fibrogenetic growth factors and their receptors are upregulated and localized with inflammatory cells in muscles of DMD patients [8]. More recently, it has been demonstrated that osteopontin, the ligand for the integrin VLA-4, is upregulated in the muscle fibers and inflammatory infiltrates in DMD patients, suggesting that it is involved in both fibrosis and inflammation [9]. A dysregulation in extracellular matrix (ECM) expression has also been demonstrated in DMD patients [10-12], together with increased expression of ECM receptors on inflammatory cells near regions of necrosis in the mdx model [13]. These data suggest that ECM-mediated cell interactions contribute to the migration of cells to the site of muscle damage, triggering and maintaining local inflammation and fibrosis.

We previously found that DMD patients exhibited higher relative numbers of $\mathrm{CD}^{+}$and $\mathrm{CD}^{+} \mathrm{T}$ cells expressing higher levels of the alpha-4 chain of the integrin VLA-4 (CD49d $\mathrm{d}^{\text {hi }}$ ) and alpha-5 chain of the integrin VLA-5 (CD49e $\left.\mathrm{e}^{\mathrm{hi}}\right)$, both of which are fibronectin receptors [14]. In the present study, we investigated if those subpopulations are correlated with disease severity and disease progression in DMD patients. We demonstrate that CD49d can be used as a biomarker to monitor both severity and progression of disease in DMD patients. In addition, ex vivo cell migration experiments strongly suggest that CD49d participates to the migration of inflammatory cells into the muscle.

To our knowledge, this is the first study that proposes a reliable circulating biomarker that can be used to stratify DMD patients into homogeneous groups thereby improving the power of significance of results of clinical trials. Finally, these results suggest that in addition CD49d could be used as a therapeutic target to slow down disease progression in DMD boys.

\section{Methods}

\section{Patients}

We enrolled 75 patients from the Pediatrics Institute, Federal University of Rio de Janeiro (IPPMG/UFRJ), Brazil (Additional file 1: Table S1), for whom the genetic and/or histological diagnosis of DMD had been confirmed. They were divided into three groups according to their ability to walk: $10 \mathrm{~m}$ in less than $10 \mathrm{~s}$ (speed $>1 \mathrm{~m} / \mathrm{s} ; n=19), 10 \mathrm{~m}$ in $10 \mathrm{~s}$ or more (speed $\leq 1 \mathrm{~m} / \mathrm{s} ; n=25)$, and unable to walk $(n=31)$. These groups were further subdivided according to the age at which they had stopped walking: before or after 10 years of age (rapid progression, $n=16$, and slow progression, $n=15$, respectively). A control group $(n=14)$ comprised age-/sex-matched healthy volunteers.

We also developed a prospective study of CD49d levels on T cells in DMD patients who were able to walk at a speed $\leq 1 \mathrm{~m} / \mathrm{s}$ and were followed until they lost their ability to walk. If such a loss occurred before 10 years of age, this was considered rapid progression, whereas after 10 years of age, it was considered slow progression.

We also evaluated biopsies from DMD patients who had lost ambulation before $(n=4)$ or after $(n=5)$ 10 years of age. The biopsies were obtained at the beginning of the disease as part of the diagnostic procedure, at Necker Children's Hospital, Paris, France (Additional file 2: Table S2). As controls, we used three age-/gender-matched muscle samples from children undergoing orthopedic surgery for non-musclerelated reasons.

Twenty-two IBM patients were enrolled for a natural history study of IBM, and their diagnosis and clinical characteristics are described [15]. Peripheral blood mononuclear cells (PBMCs) of IBM patients were compared to healthy subjects $(n=22)$, who were matched for sex and age, free of inflammatory/autoimmune diseases, past history of cancer or active cancer, and were not receiving any immunosuppressive or immunomodulatory drug. The institutional review board approved the study protocol, also for ancillary studies on their blood samples [16].

Procedures have been approved by the ethical committees of the IPPMG/UFRJ (Research and Ethical Committee of IPPMG/UFRJ-Comitê de Ética e Pesquisa do Instituto de Puericultura e Pediatria Martagão Gesteira/ Universidade Federal do Rio de Janeiro; reference number 06/06), CPP Ile de France (reference number 14.323), and the Ministère de la Recherche and Cochin Hospital Cell Bank, Paris, agreement number DC-2009944. All the patients and/or parents gave written individual informed consent to participate in the study.

\section{In situ immunofluorescence and cytofluorometry}

General features of antibodies are presented in Additional file 3, Table S3. Sequential gating of cells for CD49d evaluation is illustrated in Additional file 4, Figure S1. For cytofluorometry, we used fluorochromelabeled monoclonal antibodies with specificities for CD3, CD4, CD8, CD11a, CD14, CD19, CD49a, CD49d, $\mathrm{CD} 49 \mathrm{e}$, or CD49f. Isotype-/fluorochrome-matched unrelated antibodies were also Pharmingen reagents. Flow cytometry assays were carried out as described previously [14]. To characterize the inflammatory infiltrate in the muscle biopsies, we used anti-CD3, anti-CD4, antiCD8, anti-CD49d, and anti-HLA-DR monoclonal antibodies (mAb). Nuclei were visualized using DAPI 
(Sigma-Aldrich, St. Louis, USA). Secondary goat antimouse or goat anti-rabbit antibodies conjugated to fluorochromes (Alexa Fluor 594, Alexa Fluor 488, Streptavidin Cy5-in the case of biotinylated secondary antibody) were used to reveal primary antibodies.

In situ immunofluorescence analyses were made on frozen sections of muscle biopsies as described [17]. We performed immunostaining for simultaneous detection of CD3, CD4, or CD8; HLA-DR; and CD49d. In each muscle biopsy, all the inflammatory fields were recorded. We have also performed experiments with isotypematched unrelated reagents in the same muscle samples obtained from DMD and healthy control subjects: no background staining was observed. We performed immunostainings in samples from patients with IBM and polymyositis, and the staining patterns for CD3, $\mathrm{CD} 4$, and $\mathrm{CD} 8$ matched those described in the literature.

Images were analyzed with Metamorph software (Molecular Devices, Toronto, Canada). The absolute numbers of $\mathrm{CD}^{+}$and $\mathrm{CD} 4^{+}$cells in situ were determined in all inflammatory fields, defined by the presence of cell clusters identified with DAPI nuclear staining.

\section{Cell migration assays}

The migratory responses of $\mathrm{T}$ lymphocytes through fibronectin or endothelial cells were measured using 5$\mu \mathrm{m}$ pore size Transwell chambers (Costar; Corning). For fibronectin-driven migration, the insert membranes were coated and blocked as described [17]. For transendothelial cell migration, $10^{5}$ human umbilical vein endothelial cells (Promo Cell, Heidelberg, Germany) were added onto the insert membranes of transwell plates. After $24 \mathrm{~h}$, the cultures were confluent and the inserts were washed with RPMI-1640. In both assays, $10^{6}$ PBMCs were placed in the upper chamber and left to migrate for $16 \mathrm{~h}$. Migrating cells were phenotyped by flow cytometry. For the blocking assay, $10^{6}$ cells were pretreated for $10 \mathrm{~min}$ with $10 \mu \mathrm{l}$ of purified anti-CD49d mAb and migrated as described above. In the case of blockage of adhesion by specific antibodies, data are presented as a percentage of the migration values obtained following pretreatment with unrelated antibodies, applied on cells from the same subject. In cell migration experiments, data was normalized to measure the percentage of input, using the following formula:

$$
\begin{aligned}
\% \text { input }= & (\text { number of migrating cells of a given phenotype } \times 100) \\
& \div \text { total number of cells of a given phenotype allowed to migrate }
\end{aligned}
$$

\section{Lymphocyte adhesion to myotubes}

Human myoblasts were cultured in Ham's F-10 medium [18]. Differentiation was induced as described [19]. One million PBMCs from healthy individuals or DMD patients were allowed to adhere onto myotubes for $2 \mathrm{~h}$ at $37{ }^{\circ} \mathrm{C}$ and washed to remove non-adherent PBMCs. Adherent cells were counted and phenotyped. Unrelated IgG1 or anti-CD $49 \mathrm{~d} \mathrm{mAb}(1 \mu \mathrm{g} / \mathrm{ml})$ was added in PBMC suspensions before co-culturing with myotubes. In the case of adhesion blockage by specific antibodies, data are presented as percentages of the values obtained with unrelated antibodies, applied on cells from the same subject.

\section{Statistics}

For continuous data, groups were compared by the Mann-Whitney test (for two groups) or Kruskal-Wallis test followed by Dunn's multiple comparison test (for more than two groups). Statistical analyses were performed using GraphPad Prism software version 5 for Windows. Differences were considered statistically significant when $p$ values were $\leq 0.05$.

\section{Results}

\section{High numbers of CD49d ${ }^{\text {hi }} \mathrm{T}$ cells are correlated with disease progression}

We first evaluated the membrane expression levels of various integrin $\alpha$ subunits on circulating $\mathrm{T}$ cells, comparing a large cohort of DMD patients with healthy individuals (Table 1). We found higher relative numbers of $\mathrm{CD} 49 \mathrm{~d}^{\text {hi }} \mathrm{CD}^{+}(p=0.007)$ and $\mathrm{CD} 8^{+}$ $\mathrm{T}$ lymphocytes $(p=0.009)$ in DMD patients, although they exhibited similar numbers of $\mathrm{CD}^{+}$or $\mathrm{CD}^{+} \mathrm{T}$ cells $/ \mathrm{mm}$ in the blood compared to controls. This was specific to $\mathrm{T}$ cell subsets, since CD49d expression levels were similar in $\mathrm{CD}_{1} 9^{+} \mathrm{B}$ lymphocytes and $\mathrm{CD}_{14}{ }^{+}$monocytes, when comparing healthy and DMD subjects (Additional file 5: Figure S2).

When DMD patients were split into different subgroups, able to walk relatively fast (more than $1 \mathrm{~m} / \mathrm{s}$ ), still able to walk but more severely affected $(1 \mathrm{~m} / \mathrm{s}$ or less), and those who were no longer able to walk, the relative numbers of $\mathrm{CD} 49 \mathrm{~d}^{\text {hi }} \mathrm{CD} 4^{+}$and $\mathrm{CD} 49 \mathrm{~d}^{\mathrm{hi}} \mathrm{CD} 8^{+} \mathrm{T}$ cells were significantly higher in the more severe DMD patients, as compared to the groups $\leq 1 \mathrm{~m} / \mathrm{s}$ and unable to walk (Fig. 1a, b). No significant difference was observed between patients that could walk faster than $1 \mathrm{~m} /$ $s$ with healthy controls.

In a retrospective study of wheelchair-bound DMD patients, we observed higher percentages of $\mathrm{CD} 49 \mathrm{~d}^{\mathrm{hi}} \mathrm{CD} 4^{+}$ and $\mathrm{CD} 49 \mathrm{~d}^{\text {hi }} \mathrm{CD}^{+} \mathrm{T}$ cells in patients who had lost ambulation before 10 years of age (rapid disease progression), compared to those who had become wheelchair bound at or after 10 years of age (slow disease progression) (Fig. 1c). These findings clearly indicate that higher numbers of $C D 49 \mathrm{~d}^{\text {hi }} \mathrm{T}$ cells correlate with rapid disease progression. 
Table 1 Higher relative numbers of circulating $\mathrm{CD}^{+}$and $\mathrm{CD}^{+}$ $T$ cell subsets expressing high densities of CD49d in patients with Duchenne muscular dystrophy

\begin{tabular}{|c|c|c|c|}
\hline \multirow{2}{*}{$\begin{array}{l}\text { T cell } \\
\text { subpopulation }\end{array}$} & \multicolumn{2}{|c|}{ Relative cell number (mean $\pm \mathrm{SD})^{\mathrm{a}}$} & \multirow[t]{2}{*}{$p$ value } \\
\hline & Healthy & DMD & \\
\hline $\mathrm{CD}^{+} \mathrm{CD}_{49} \mathrm{a}^{\mathrm{hi}}$ & $3.66 \pm 2.80$ & $4.34 \pm 3.18$ & 0.75 \\
\hline $\mathrm{CD}^{+} \mathrm{CD}_{49} \mathrm{a}^{\mathrm{hi}}$ & $3.81 \pm 3.25$ & $4.02 \pm 3.66$ & 0.93 \\
\hline$C D 4^{+} C D 49 d^{\text {hi }}$ & $23.25 \pm 5.86$ & $29.72 \pm 8.66$ & 0.007 \\
\hline $\operatorname{CD} 8^{+} C D 49 d^{\text {hi }}$ & $26.28 \pm 5.89$ & $34.66 \pm 12.00$ & 0.009 \\
\hline $\mathrm{CD} 4^{+} \mathrm{CD} 49 \mathrm{e}^{\mathrm{hi}}$ & $34.95 \pm 9.28$ & $34.97 \pm 7.70$ & 0.87 \\
\hline $\mathrm{CD} 8^{+} \mathrm{CD} 49 \mathrm{e}^{\mathrm{hi}}$ & $31.10 \pm 8.17$ & $34.04 \pm 13.42$ & 0.46 \\
\hline $\mathrm{CD} 4^{+} \mathrm{CD} 49 \mathrm{f}^{\mathrm{hi}}$ & $30.53 \pm 7.60$ & $27.85 \pm 9.37$ & 0.36 \\
\hline $\mathrm{CD}^{+} \mathrm{CD} 49 \mathrm{f}^{\mathrm{hi}}$ & $18.73 \pm 5.37$ & $18.34 \pm 7.75$ & 0.65 \\
\hline $\mathrm{CD} 4^{+} \mathrm{CD} 11 \mathrm{a}^{\mathrm{hi}}$ & $22.71 \pm 14.23$ & $19.30 \pm 12.80$ & 0.60 \\
\hline $\mathrm{CD} 8^{+} \mathrm{CD} 11 \mathrm{a}^{\mathrm{hi}}$ & $38.31 \pm 11.39$ & $44.64 \pm 11.30$ & 0.33 \\
\hline
\end{tabular}

${ }^{\mathrm{a}}$ Data are presented as relative cell numbers of $\mathrm{T}$ cell subsets expressing high levels of a given integrin subunit. Numbers in italics illustrate statistically significant differences between normal subjects and Duchenne muscular dystrophy (DMD) patients, with corresponding $p$ values

In a prospective study of $23 \mathrm{DMD}$ patients followed until loss of ambulation, we found that a significantly higher number of $\mathrm{CD} 49 \mathrm{~d}^{\text {hi }} \mathrm{CD} 4^{+}$and $\mathrm{CD} 49 \mathrm{~d}^{\text {hi }} \mathrm{CD} 8^{+} \mathrm{T}$ cells were observed at the beginning of the study in the group of patients who subsequently lost ambulation before 10 years of age $(n=12)$, as compared to those in the group who lost ambulation later $(n=11)$. These results confirm that the relative number of circulating CD49 $\mathrm{d}^{\text {hi }}$ $\mathrm{T}$ cells can predict disease progression (Fig. 1d). If we look for the relative numbers of both subpopulations, we observed that DMD patients with $\mathrm{CD} 49 \mathrm{~d}^{\mathrm{hi}} \mathrm{CD} 4^{+} \geq$ $31.91 \%$ and $\mathrm{CD} 49 \mathrm{~d}^{\mathrm{hi}} \mathrm{CD}^{+}{ }^{+} \mathrm{T}$ cells $\geq 45.90 \%$ have $100 \%$ chance to lose ambulation before 10 years of age (sensitivity of $41 \% ; x^{2}=5.85 ; p=0.01$ ). This will be very important when carrying out clinical trials for new drugs in the future.

Since no statistical difference in levels of circulating CD49d ${ }^{\text {hi }} \mathrm{T}$ cells could be observed between $\leq 1 \mathrm{~m} / \mathrm{s}$ ambulating versus non-ambulating patients, we thus split the patients into two groups (slow progressors: unable to walk with 10 years or more, and fast progressors: unable to walk before 10 years) and check the numbers of CD49 $\mathrm{d}^{\mathrm{hi}} \mathrm{T}$ cells just as a function of disease progression. For the slow progressors, no significant difference was found between $\leq 1 \mathrm{~m} / \mathrm{s} \quad(n=11)$ and non-ambulating $(n=15)$ patients. For the fast progressors, we observed higher numbers of CD49 $\mathrm{d}^{\text {hi }}$ $\mathrm{T}$ cells in non-ambulating patients $(n=16)$ when compared to $\leq 1 \mathrm{~m} / \mathrm{s}$ patients $(n=12)$ (Additional file 6: Figure S3).

We performed the same analyses in a longitudinal study, following the same patient over time $(\leq 1 \mathrm{~m} / \mathrm{s}$ and unable to walk). Again, we observed higher numbers of
CD $49 \mathrm{~d}^{\text {hi }} \mathrm{CD} 4^{+} \mathrm{T}$ cells when the patient became unable to walk comparing with $\leq 1 \mathrm{~m} / \mathrm{s}$ only in the group of fast progressors $(n=4)$ (Additional file 6: Figure S3).

To investigate whether CD49 $\mathrm{d}^{\mathrm{hi}}$ is also a common biomarker in patients with inflammatory disorders of the skeletal muscle, we investigated the relative numbers of CD $49 \mathrm{~d}^{\text {hi }} \mathrm{T}$ cells from patients with inclusion body myositis (IBM), an example of an inflammatory disorder of the skeletal muscle [20]. It is important to note that no difference was observed when IBM patients were compared to healthy controls (Table 2), further reinforcing the role of the relative numbers of $C D 49 \mathrm{~d}^{\text {hi }} \mathrm{T}$ as a biomarker for DMD severity in patients with established genetic diagnosis.

\section{$\mathrm{CD} 4 \mathrm{~d}^{+}$-activated $\mathrm{T}$ lymphocytes in inflammatory infiltrates}

We investigated CD49d in T cells within the skeletal muscle of nine DMD patients. Initial analysis showed no difference in the numbers of $\mathrm{CD} 4^{+} \mathrm{T}$ cells and a trend to a higher number of $\mathrm{CD}^{+} \mathrm{T}$ lymphocytes within the inflammatory infiltrate (Fig. 2a) in the muscle of rapidprogressing DMD patients. However, when we applied HLA-DR immunostaining as a $\mathrm{T}$ cell activation marker, we detected significantly higher numbers of tissueresident $\mathrm{CD} 49 \mathrm{~d}^{+} \mathrm{HLA}-\mathrm{DR}^{+} \mathrm{CD} 8^{+} \mathrm{T}$ lymphocytes (but not CD49d $\mathrm{d}^{+}$HLA-DR ${ }^{+} \mathrm{CD} 4^{+} \mathrm{T}$ cells) in patients who had a rapid disease progression (Fig. 2b) $(p<0.05)$.

\section{CD49d-mediated T cell migratory responses correlate with disease progression}

We next investigated the transendothelial migration of CD49d-positive $\mathrm{T}$ cells isolated from the different subgroups of DMD patients with different disease severity. We observed that transendothelial migration of $\mathrm{CD} 49 \mathrm{~d}^{\mathrm{hi}} \mathrm{CD} 4^{+}$and $\mathrm{CD} 49 \mathrm{~d}^{\mathrm{hi}} \mathrm{CD} 8^{+} \mathrm{T}$ cells was higher when isolated from DMD patients than from their healthy counterparts $(p<0.05$ and $p<0.01$, respectively). More importantly, we observed that $\mathrm{CD} 49 \mathrm{~d}^{\mathrm{hi}} \mathrm{CD}^{+} \mathrm{T}$ cells from wheelchair-bound DMD patients migrated faster through an endothelial layer than those isolated from less severe DMD patients, still able to walk faster than $1 \mathrm{~m} / \mathrm{s}(p<0.05)$ (Fig. 3a).

Since CD49d is a fibronectin receptor, we tested if its increase was functional by investigating whether $\mathrm{T}$ lymphocytes from DMD patients would migrate faster through a fibronectin lattice. Higher fibronectindriven $\mathrm{CD}^{+} \mathrm{T}$ cell migratory responses were positively correlated with disease progression $(p<0.01)$ (Fig. 3b), being statistically significant for CD $49 \mathrm{~d}^{\text {hi }} \mathrm{CD}^{+}$and $\mathrm{CD} 49 \mathrm{~d}^{\text {hi }} \mathrm{CD} 8^{+}$T cells $(p<0.001$ and $p<0.05$, respectively) (Fig. $3 \mathrm{~b}$ ) when compared to healthy controls. 


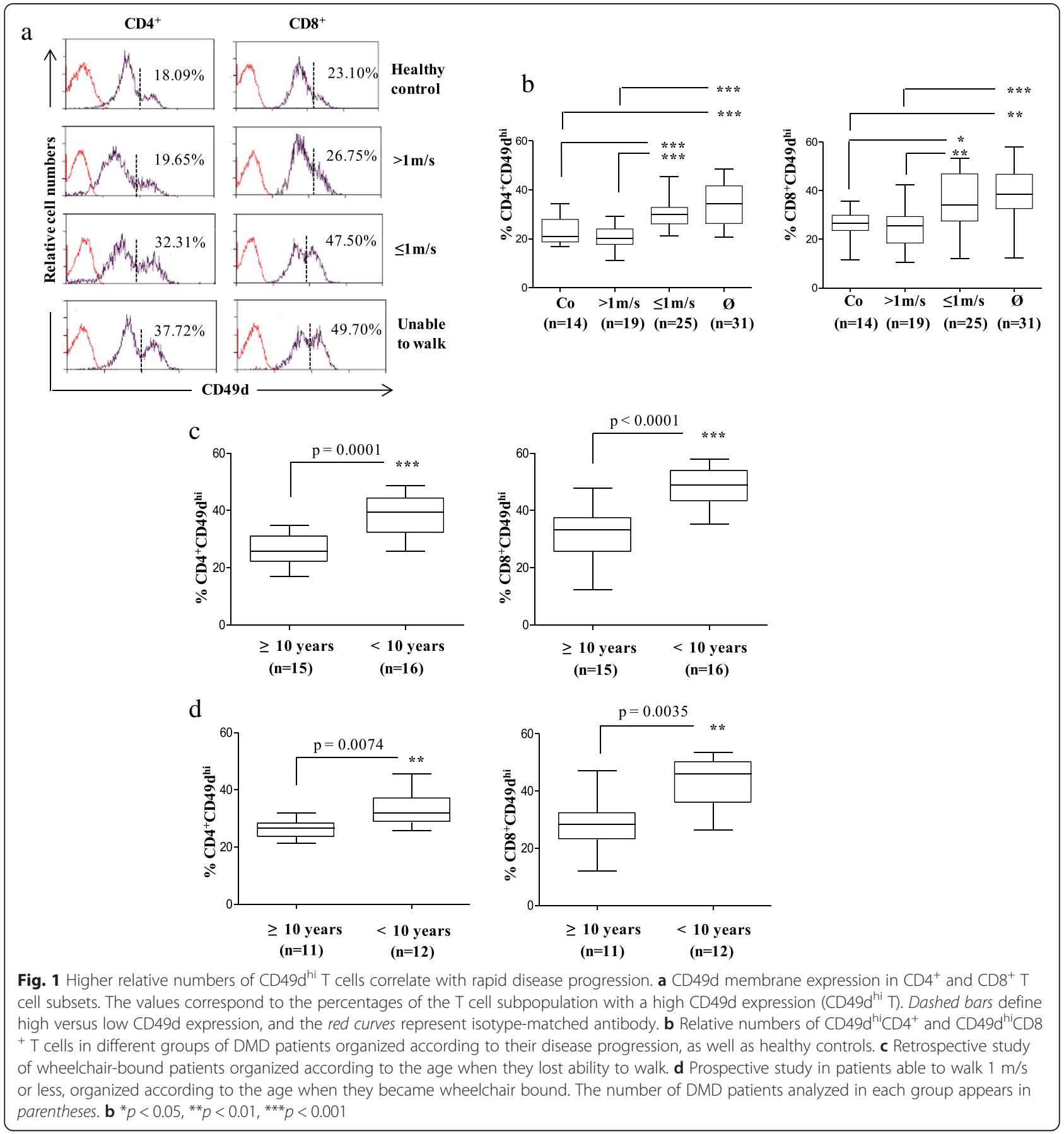

Table 2 No difference was observed in the relative numbers of circulating $C D 4^{+}$and $C D 8^{+} T$ cell subsets expressing high densities of CD49d in patients with IBM and healthy controls

\begin{tabular}{|c|c|c|c|c|c|}
\hline \multirow{2}{*}{$\begin{array}{l}\text { T cell } \\
\text { subpopulation }\end{array}$} & \multicolumn{2}{|c|}{ Relative cell number $(\text { mean } \pm S D)^{a}$} & \multirow[t]{2}{*}{$p$ value } & \multicolumn{2}{|c|}{ Number of individuals } \\
\hline & Healthy & IBM & & Healthy & $\mathrm{IBM}$ \\
\hline $\mathrm{CD}^{+}{ }^{+} \mathrm{CD}_{49} \mathrm{~d}^{\mathrm{hi}}$ & $35.24 \pm 13.10$ & $34.23 \pm 18.25$ & 0.44 & 21 & 23 \\
\hline $\mathrm{CD}^{+} \mathrm{CD}^{+} 9 \mathrm{~d}^{\mathrm{hi}}$ & $44.89 \pm 14.66$ & $43.92 \pm 14.59$ & 0.60 & 17 & 20 \\
\hline
\end{tabular}

${ }^{\mathrm{a}}$ Data are presented as relative cell numbers of T cell subsets expressing high levels of the CD49d integrin subunit. No significant differences ( $p>0.05$ ) were seen in both T cell subpopulations when healthy patients were compared to IBM individuals 

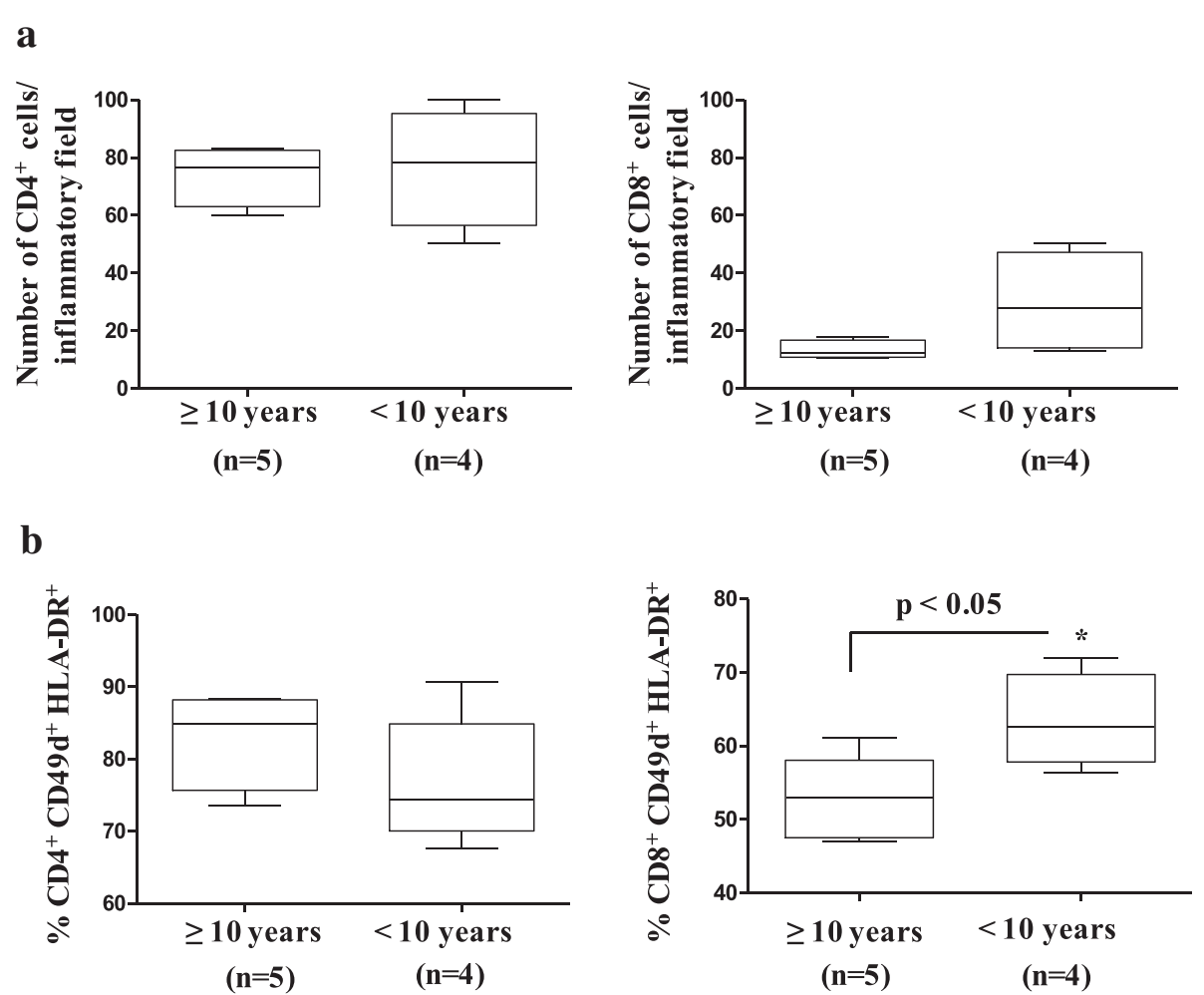

Fig. 2 Higher numbers of activated $C D 8^{+} C D 49 d^{+} T$ cells in muscle of DMD patients with rapid progression. a Number of $C D 4^{+}$and $C D 8^{+}$ $\mathrm{T}$ lymphocytes per inflammatory infiltrate. $\mathbf{b}$ Relative number of $\mathrm{T}$ cells simultaneously expressing CD49d and the $\mathrm{T}$ cell activation marker HLA-DR. The biopsies were performed at the beginning of the disease, and patients were divided into two groups according to the age when they became wheelchair bound. The number of DMD patients analyzed in each group appears in parentheses

Considering that integrins are involved in leukocyte proliferation and survival [12], and that VLA-4 interaction with fibronectin induces lymphocyte proliferation, we evaluated cell proliferation and cell death after the 16-h migration period in the different groups of patients. No differences were observed (data not shown), indicating that the increased migratory responses are not related to increased proliferation or cell survival.

\section{Anti-CD49d mAb blocks transendothelial, fibronectin- driven migration and myotube adhesion of $T$ cells from DMD patients}

Because the VLA-4/VCAM-1 interaction on the surface of endothelial cells is important for transmigration of $\mathrm{T}$ cells from the blood, and considering that the VLA-4/fibronectin interaction is important for cell migration within the tissues, we investigated whether we could abrogate the migration of $\mathrm{T}$ cells ex vivo by selectively blocking CD49d. We pretreated $\mathrm{T}$ cells with an anti$\mathrm{CD} 49 \mathrm{~d} \mathrm{mAb}$ and compared their migration with that of $\mathrm{T}$ cells treated with an unrelated isotype-matched Ig. Anti-CD49d pretreatment efficiently and preferentially blocked transendothelial $(p<0.001)$ and fibronectindriven migration of $\mathrm{CD} 49 \mathrm{~d}^{\mathrm{hi}} \mathrm{CD} 4^{+} \quad(p<0.05)$ and
CD49d $\mathrm{d}^{\text {hi }} \mathrm{CD}^{+}(p<0.01) \mathrm{T}$ cells isolated from DMD patients (Fig. 4a, b). Moreover, since DMD-derived $\mathrm{CD} 49 \mathrm{~d}^{\text {hi }} \mathrm{CD} 4^{+}(p<0.001)$ and $\mathrm{CD} 49 \mathrm{~d}^{\mathrm{hi}} \mathrm{CD} 8^{+}(p<0.01) \mathrm{T}$ cells exhibited a higher adhesion onto monolayers of human myotubes (Fig. 4c), we tested the effect of blocking CD49d (Additional file 7: Figure S4a). The anti-CD49 mAb treatment significantly abrogated $\mathrm{CD} 49 \mathrm{~d}^{\text {hi }} \mathrm{CD} 4{ }^{+}$ and $\mathrm{CD} 49 \mathrm{~d}^{\mathrm{hi}} \mathrm{CD} 8^{+} \mathrm{T}$ cell adhesion $(p<0.05$ and $p<0.01$, respectively), and in the case of $\mathrm{CD} 8^{+} \mathrm{CD} 49 \mathrm{~d}^{\text {hi }} \mathrm{T}$ cell subsets, values were similar to those seen when control Ig was applied on lymphocytes from healthy individuals (Fig. 4c). Moreover, anti-CD49d pretreatment preferentially blocked the adhesion of CD49d ${ }^{\text {hi }} \mathrm{CD}^{+}(\mathrm{p}=0.02) \mathrm{T}$ cells (Additional file 7: Figure S4b). These results provide a proof of concept to design a therapeutic intervention to minimize the accelerating effect of increased CD49d $\mathrm{d}^{\text {hi }} \mathrm{T}$ cells, and of exacerbated inflammation, on the progression of the DMD phenotype.

\section{Discussion}

We demonstrate that circulating CD49 $\mathrm{d}^{\text {hi }} \mathrm{T}$ cells can be successfully used as a biomarker for disease progression in DMD patients. Moreover, this seems to be specific for 
(a) Transendothelial cell migration assay
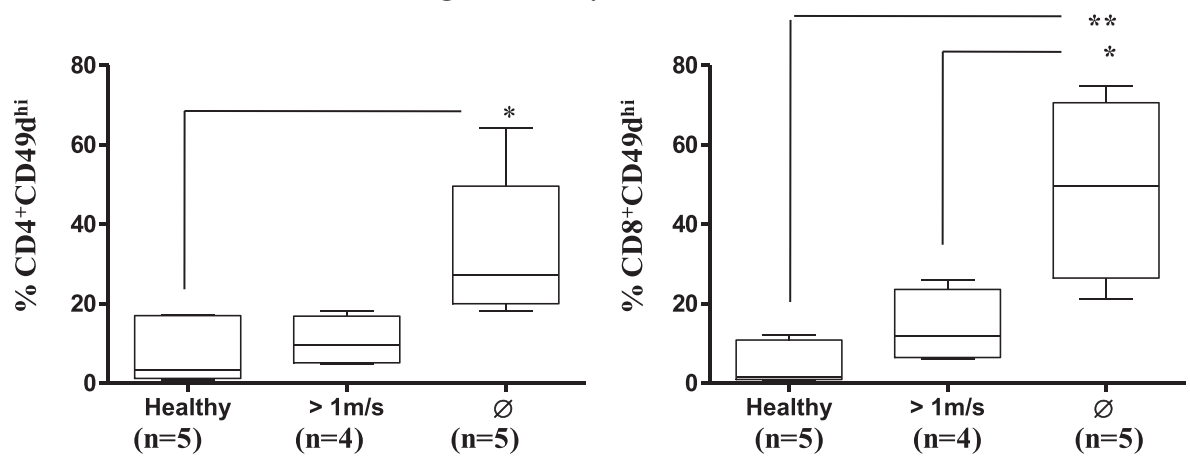

(b) Fibronectin-driven cell migration assay
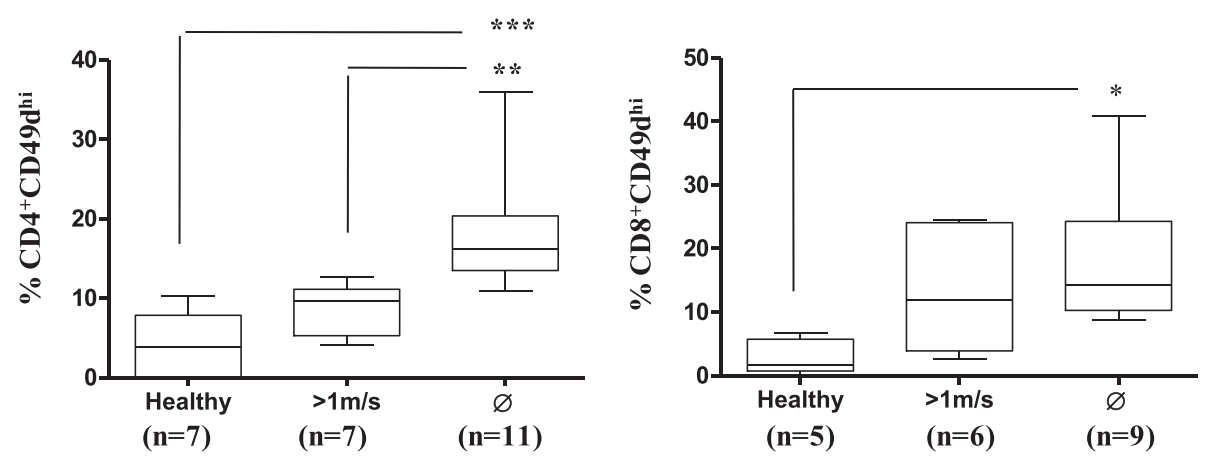

Fig. 3 Enhanced migratory response of T lymphocytes from DMD patients correlates with disease severity. a Migration of T lymphocytes through endothelial cells. $\mathbf{b}$ Fibronectin-driven migration. Relative numbers of CD $49 \mathrm{~d}^{\text {hi }} C D 4^{+}$and $C D 49 \mathrm{~d}^{\text {hi }} C D 8^{+}$migrating cells in healthy controls and in the different groups of DMD patients, subdivided according to their ability to walk. The number of DMD patients analyzed in each group appears in parentheses. ${ }^{*} p<0.05,{ }^{* *} p<0.01,{ }^{* * *} p<0.001$

DMD since it is not found in IBM patients, who also suffer from an inflammatory muscle disease.

The percentages of circulating $\mathrm{CD} 49 \mathrm{~d}^{\text {hi }} \mathrm{CD} 4^{+}$and CD49 $\mathrm{d}^{\text {hi }} \mathrm{CD}^{+} \mathrm{T}$ lymphocytes in DMD subjects correlated with disease prognosis in both ambulant and non-ambulant patients. Importantly, rapid disease progression in DMD patients can be predicted by detecting increased numbers of circulating $\mathrm{CD} 49 \mathrm{~d}^{\mathrm{hi}} \mathrm{CD} 4^{+}$ and $C D 49 \mathrm{~d}^{\text {hi }} \mathrm{CD}^{+} \mathrm{T}$ lymphocytes at the beginning of the disease. This is also in agreement with our previous report, showing that decreased stride frequency and increased $C D 49 \mathrm{~d}^{\text {hi }} \mathrm{CD} 4^{+} \mathrm{T}$ lymphocytes are predictive markers of clinical outcome in the GRMD dog model of DMD [21]. Therefore, we propose that for the fast progressors, CD49d can be a biomarker for the prognosis and also for disease severity, since the frequencies of CD49d $\mathrm{d}^{\text {hi }} \mathrm{T}$ cells increase progressively once the patient begins to walk in $1 \mathrm{~m} / \mathrm{s}$ or less. This fits with the hypothesis that CD49d can be involved in the pathogenesis of the muscular lesions.

Corticotherapy is widely used to improve DMD phenotype, and the chronic use of corticotherapy could modify the percentages of the CD $49 \mathrm{~d}^{\text {hi }} \mathrm{T}$ cells. However, this is not the case since the patients who were no longer able to walk had stopped steroid treatment before the analyses, and the changes in CD49d expression persisted. In addition, it has been reported that glucocorticoids do not modulate in vitro or in vivo CD49d expression [22, 23]. Furthermore, all patients who were still able to walk were all under steroid treatment, thus excluding steroid treatment as a putative confounder. Yet, one can argue that good responders to glucocorticoids have a lower degree of inflammation and, as a consequence, lower levels of CD49 $\mathrm{d}^{\text {hi }} \mathrm{T}$ cells. When we followed the same patient at two different time points of disease $(\leq 1 \mathrm{~m} / \mathrm{s}$ : all under with corticotherapy, and unable to walk: with no longer corticosteroid treatment), we clearly found that the frequency of CD49d ${ }^{\text {hi }} \mathrm{CD} 4+\mathrm{T}$ cells increased along with progression of severity only in the fast progressors. Considering that both groups (fast and slow progressors) were under the same conditions regarding corticotherapy, it suggests that the frequency of $\mathrm{CD} 49 \mathrm{~d}^{\text {hi }} \mathrm{CD} 4^{+} \mathrm{T}$ cells is not influenced by this drug. This individual follow-up with a small number of patients is supported by the same analysis in a transversal study with a larger cohort (Additional file 6: Figure S3a, 


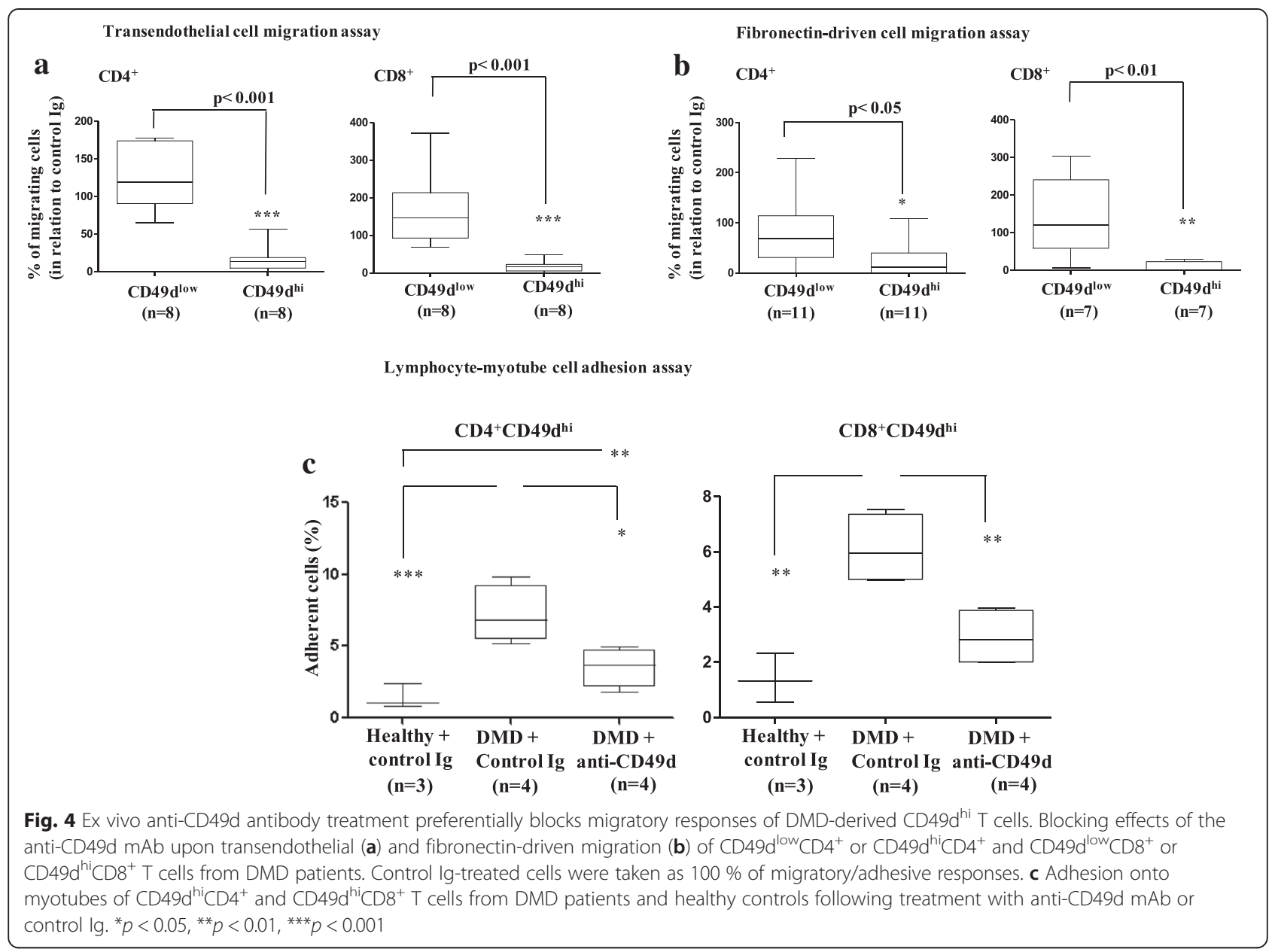

b, e, f). CD49d can thus be used for clinical trials to stratify DMD patients into predictive slow and rapid progressors, whether these patients are under steroid treatment or not.

Using the T cell activation marker HLA-DR, we found a positive correlation with the relative number of CD49d ${ }^{\text {hi }}$ HLA-DR ${ }^{+} \mathrm{CD}^{+}{ }^{+} \mathrm{T}$ lymphocytes in the blood of patients who became wheelchair bound before 10 years of age. We also found more activated CD49d $\mathrm{d}^{+}$HLA$\mathrm{DR}^{+} \mathrm{CD} 8^{+} \mathrm{T}$ cells in the muscle of rapid progressors. Together, these findings support the concept that this subpopulation plays an important role in the pathogenesis of DMD and that the higher the relative number of CD49 $\mathrm{d}^{\text {hi }} \mathrm{T}$ cells in the blood, the more rapid is the disease progression.

More importantly, we show that both transendothelial and fibronectin-driven migration of CD49 $\mathrm{d}^{\text {hi }} \mathrm{T}$ cells from DMD patients were enhanced, as well as the binding of CD49 $\mathrm{d}^{\text {hi }} \mathrm{T}$ lymphocytes to myotubes. Considering that there was a correlation between the highest numbers of CD49 $\mathrm{d}^{\text {hi }} \mathrm{T}$ cells, the poor prognosis and disease severity, the highest migration, and the already known function of CD49d in the interaction with endothelium and fibronectin, we propose as an hypothesis that CD49d may facilitate $\mathrm{T}$ cell migration into muscle tissue. This suggests that CD49d acts by accelerating the migration of the $\mathrm{T}$ cells into the muscle, consequently enhancing inflammatory infiltrate in dystrophic muscle and directly targeting muscle fibers. Pretreatment of DMD T cells with an anti-CD49d mAb prevented transendothelial migration and decreased the ability of these cells to attach to myotubes. These findings strongly suggest that treatment with an anti-CD49d mAb may decrease in vivo the transendothelial migration of the $\mathrm{T}$ cells, impair their interaction with fibronectin within skeletal muscle, and abrogate cell-cell adhesive interactions with muscle fibers to slow down eventual necrosis.

It is important to mention that the pretreatment with anti-CD49d decreased the transendothelial and fibronectin-driven migration of CD49 $\mathrm{d}^{\text {hi }} \mathrm{T}$ cells but increased migration of $\mathrm{CD} 49 \mathrm{~d}^{\text {low }} \mathrm{T}$ lymphocytes. In principle, cells with low expression of CD49d represent $\mathrm{T}$ cells that are not activated. In this regard, the influx into the muscle would not be a problem since non-activated cells would recirculate. In a second vein, $\mathrm{CD} 49 \mathrm{~d}^{\text {low }} \mathrm{CD} 4^{+} \mathrm{T}$ lymphocytes may correspond 
to regulatory $\mathrm{T}$ cells. If this is the case, they will rather have a protective anti-inflammatory role upon the entrance of activated $\mathrm{CD} 49 \mathrm{~d}^{\mathrm{hi}} \mathrm{HLA}-\mathrm{DR}^{+} \mathrm{CD} 4^{+} \mathrm{T}$ lymphocytes. Of note, we did not observe the same kind of event when lymphocytes were led to adhere onto myotubes. In those sets of experiments, no enhancement in the adhesion was observed regarding the CD49d ${ }^{\text {low }} \mathrm{T}$ cells. Actually, a blockade of both low and high subpopulations seemed to occur after the pretreatment in vitro, being however more important in CD49d $\mathrm{d}^{\text {hi }} \mathrm{T}$ cells when compared to the corresponding low subpopulation. No difference was observed between low and high $\mathrm{CD}^{+} \mathrm{T}$ cells. Yet, considering the short number of patients studied, more experiments should be done to clarify this point.

The anti-CD49d mAb Natalizumab has already been used to treat multiple sclerosis and inflammatory bowel disease [24] and has proved to be beneficial for several thousands of patients [25-27], even though progressive multifocal leukoencephalopathy was reported in $0.08-0.03 \%$ of patients treated for at least 24 months. Natalizumab has been well tolerated by children suffering from multiple sclerosis, resulting in clinical benefits [28]. Since DMD patients have high numbers of circulating CD49d ${ }^{\text {hi }} \mathrm{T}$ cells as well as of $\mathrm{CD}_{4} 9 \mathrm{~d}^{+} \mathrm{T}$ cells within the muscle, the therapeutic targeting of CD49d could be beneficial, and clinical trials should be envisaged to confirm this effect.

\section{Conclusions}

We propose that CD49d can be used as a novel prognostic biomarker to stratify DMD patients into homogeneous cohorts in future clinical trials, improving potentially the significance of these costly studies. Inhibition of CD49d-mediated interactions could be envisioned as a novel therapeutic strategy for improving disease progression in DMD patients, by decreasing the immune response, in conjunction with other gene therapy approaches such as exon skipping or gene replacement, which in some cases triggers dystrophin-specific immune response [29-31].

\section{Additional files}

Additional file 1: Table S1. General characteristics of the DMD patients enrolled in the study of blood samples. (DOC $35 \mathrm{~kb}$ )

Additional file 2: Table S2. Age-related features of DMD patients enrolled in the evaluation of muscle biopsies. (DOC 37 kb)

Additional file 3: Table S3. Antibodies applied in cytofluorometry and immunohistochemistry. (DOC 57 kb)
Additional file 4: Figure S1. Gating procedures for cytofluorometric labeling of CD49d in freshly isolated leukocytes from the blood of normal subjects and Duchenne muscular dystrophy patients. (DOC $108 \mathrm{~kb}$ )

Additional file 5: Figure S2. Lack of differences between DMD patients and healthy control in relative numbers of CD14/CD49d $\mathrm{d}^{\text {hi }}$ and CD19/ CD49d hi cells. (DOC 69 kb)

Additional file 6: Figure S3. Higher numbers of CD49 $d^{\text {hi }}$ T cells in fast, but not in slow, progressors DMD patients correlate with disease severity. (DOC 59 kb)

Additional file 7: Figure S4. Ex vivo anti-CD49d antibody treatment blocks lymphocyte-myotube adhesion in DMD patients. (DOC 520 kb)

\section{Abbreviations}

DMD: Duchenne muscular dystrophy; ECM: extracellular matrix; Ig: immunoglobulin; mAb: monoclonal antibody; VLA: very late antigen.

\section{Competing interests}

The authors declare that they have no competing interests.

\section{Authors' contributions}

FPM designed and performed flow cytometry as well as cell migration experiments, analyzed all the data, and wrote the manuscript. LRC performed flow cytometry and culture experiments and participated in cell migration and adhesion experiments. WdM participated in flow cytometry and experiments involving cell migration and helped with the writing of the manuscript. AQCA coordinated the cohort of DMD patients, designed experiments, and wrote the manuscript. MCSAC participated in the stratification of DMD patients and in writing the manuscript. MGR participated in the stratification of DMD patients and in writing the manuscript. PHC participated in some analyses of the patients and in the whole statistical analysis of experiments. IR participated in the immunohistochemistry experiments and in writing the manuscript. EN participated in the immunohistochemistry experiments and made substantial contribution to conceptions and analyzing data. ID has been responsible for the human biopsy fragments and participated in the analysis of immunohistochemistry data and in writing the manuscript. MV participated in flow cytometry experiments with DMD patients and analyzed the data. EY performed flow cytometry experiments with IBM patients and analyzed the data. YA performed flow cytometry experiments with IBM patients. OB has provided the IBM patient cohort, made substantial contributions to conceptions, and evaluated part of the data. TV participated in designing some experiments, as well as in analyzing the data and writing the manuscript. VM participated in designing some experiments, providing the human myoblasts, as well as in analyzing the data and writing the manuscript. SDSB designed the whole study and wrote the manuscript. GBB participated in designing some experiments, analyzing the data, and writing the manuscript. WS designed the whole study and wrote the manuscript. All authors were involved in drafting and revising the manuscript critically for important intellectual content, gave final approval of the version to be published, and agreed to be accountable for all aspects of the work in ensuring that questions related to the accuracy or integrity of any part of the work are appropriately investigated and resolved. All authors read and approved the final manuscript.

\section{Acknowledgements}

I, Gillian Butler-Browne, acknowledge that all the persons mentioned herein have read and agree with the present submission.

We thank Eduardo Pernambuco and Cristiane Mello Vieira (Pediatrics Institute, Federal University of Rio de Janeiro) for obtaining the blood samples from all patients enrolled in this study.

We thank PAPES/Fiocruz, CAPES, FAPERJ, CNPq (Brazil), FOCEM (Mercosur), United Parent's Project for Muscular Dystrophies (UPPMD), Inserm, UPMC, CNRS, Association Française contre les Myopathies (AFM), ANR (Genopath INAFIB), MyoAge (EC 7th FP, contract 223576), Inserm/Fiocruz, and CNPq/ Inserm Conjoint Programs for the financial support. This work was developed in the context of the CNPq/Inserm/Fiocruz/UPMC International Associated Laboratory on Cell Therapy and Immunotherapy. 


\section{Author details}

'Laboratory on Thymus Research, Oswaldo Cruz Foundation, Rio de Janeiro, Brazil. ${ }^{2}$ Institute of Pediatrics, Federal University of Rio de Janeiro, Rio de Janeiro, Brazil. ${ }^{3}$ Sorbonne Universités, UPMC Univ Paris 06, UM76, INSERM U974, CNRS FRE3617, Center for Research in Myology, 47 boulevard de I'Hopital, Paris 75651, France. ${ }^{4}$ Laboratory on Human Genetics, Oswaldo Cruz Institute, Oswaldo Cruz Foundation, Rio de Janeiro, Brazil. ${ }^{5}$ INSERM U-E10, Necker Hospital, Paris, France. ${ }^{6}$ Service de Médecine Interne 1, Université Pierre et Marie Curie, Paris, France. ${ }^{7}$ Department of Clinical Research, National Cancer Institute (INCA), Rio de Janeiro, Brazil.

Received: 7 June 2015 Accepted: 3 November 2015

Published online: 10 December 2015

\section{References}

1. Monaco A, Neve R, Colletti-Feener C, Bertelson CJ, Kurnit DM, Kunkel LM. Isolation of candidate cDNAs for portions of the Duchenne muscular dystrophy gene. Nature. 1986;323(6089):646-50.

2. Hoffman E, Brown R, Kunkel L. Dystrophin: the protein product of the Duchenne muscular dystrophy locus. Cell. 1987;51(6):919-28.

3. Falzarano MS, Passarelli C, Ferlini A. Nanoparticle delivery of antisense oligonucleotides and their application in the exon skipping strategy for Duchenne muscular dystrophy. Nucleic Acid Ther. 2014;24(1):87-100.

4. Clinicaltrials.gov identifier NCT01254019.

5. Desguerre I, Mayer M, Leturcq F, Barbet JP, Gherardi RK, Christov C. Endomysial fibrosis dystrophy: a marker of poor outcome associated with macrophage alternative activation. J Neuropathol Exp Neurol. 2009;68(7):762-73.

6. Klingler W, Jurkat-Rott K, Lehmann-Horn F, Schleip R. The role of fibrosis in Duchenne muscular dystrophy. Acta Myol. 2012;31(3):184-95.

7. Farini A, Meregalli M, Belicchi M, Battistelli M, Parolini D, D'Antona G, et al. $T$ and $B$ lymphocyte depletion has a marked effect on the fibrosis of dystrophic skeletal muscles in the scid/mdx mouse. J Pathol. 2007;213(2):229-38.

8. Zhou L, Lu H. Targeting fibrosis in Duchenne muscular dystrophy. J Neuropathol Exp Neurol. 2010;69(8):771-6.

9. Zanotti S, Gibertini S, Di Blasi C, Cappelletti C, Bernasconi P, Mantegazza R, et al. Osteopontin is highly expressed in severely dystrophic muscle and seems to play a role in muscle regeneration and fibrosis. Histopathology. 2011;59(6):1215-28.

10. Seixas SI, Wajsenzon IJ, Savino W, Quírico-Santos T. Altered deposition of extracellular matrix components in the skeletal muscle and lymph node of the MDX dystrophic mouse. Braz J Med Biol Res. 1994;27:2229-40.

11. Hantaï D, Labat-Robert J, Grimaud JA, Fardeau M. Fibronectin, laminin, type I, III and IV collagens in Duchenne's muscular dystrophy, congenital muscular dystrophies and congenital myopathies: an immunocytochemical study. Connect Tissue Res. 1985;13(4):273-81.

12. Rampoldi E, Meola G, Conti AM, Velicogna M, Larizza L. A comparative analysis of collagen III, IV, laminin and fibronectin in Duchenne muscular dystrophy biopsies and cell cultures. Eur J Cell Biol. 1986;42:27-34.

13. Lagrota-Candido J, Canella I, Savino W, Quirico-Santos T. Expression of extracellular matrix ligands and receptors in the muscular tissue and draining lymph nodes of mdx dystrophic mice. Clin Immunol. 1999;93:143-51.

14. Pinto-Mariz F, Carvalho LR, de Mello W, Araújo AQC, Ribeiro MG, Cunha MCSA, et al. Differential integrin expression by T lymphocytes: potential role in DMD muscle damage. J Neuroimmunol. 2010;223:128-30.

15. Allenbach $Y$, Benveniste $O$, Decostre V, Canal A, Eymard B, Herson S, et al. Quadriceps strength is a sensitive marker of disease progression in sporadic inclusion body myositis. Neuromuscul Disord. 2012;22(11):980-6.

16. ClinicalTrials.gov Identifier: NCT00898989.

17. Silva-Barbosa SD, Butler-Browne GS, de Mello W, Riederer I, Di Santo JP, Savino W, et al. Human myoblast engraftment is improved in lamininenriched microenvironment. Transplantation. 2008;85:566-75.

18. Edom F, Mouly V, Barbet JP, Fiszman MY, Butler-Browne GS. Clones of human satellite cells can express in vitro both fast and slow myosin heavy chains. Dev Biol. 1994;164:219-29.

19. Bigot A, Jacquemin V, Debacq-Chainiaux F, Butler-Browne GS, Toussaint O, Furling $D$, et al. Replicative aging down-regulates the myogenic regulatory factors in human myoblasts. Biol Cell. 2008;100:189-99.

20. Greenberg SA. Pathogenesis and therapy of inclusion body myositis. Curr Opin Neurol. 2012;25:630-9.
21. Barthélémy I, Pinto-Mariz F, Yada E, Desquilbet L, Savino W, Silva-Barbosa SD, et al. Predictive markers of clinical outcome in the GRMD dog model of Duchenne muscular dystrophy. Dis Model Mech. 2014;7(11):1253-61.

22. Luján S, Masjuan J, Roldán E, Villar LM, González-Porqué P, Alvarez Cermeño JC. The expression of integrins on activated $T$ cell in multiple sclerosis. Effect of intravenous methylprednisolone treatment. Mult Scler. 1998;4:239-42.

23. Hughes JM, Sewell WA, Black L, Armour CL. Effect of dexamethasone on expression of adhesion molecules on CD4 ${ }^{+}$lymphocytes. Am J Physiol. 2006:271:79-84.

24. Bickston SJ, Muniyappa K. Natalizumab for the treatment of Crohn's disease. Expert Rev Clin Immunol. 2010;6:513-9.

25. Fernández O, Alvarenga MP, Guerrero M, León A, Alonso A, López-Madrona JC, et al. The efficacy of natalizumab in patients with multiple sclerosis according to level of disability: results of an observational study. Mult Scler. 2011;17:192-7.

26. Piehl F, Holmén C, Hillert J, Olsson T. Swedish natalizumab (Tysabri) multiple sclerosis surveillance study. Neurol Sci. 2011;31:289-93.

27. laffaldano $P, D^{\prime}$ Onghia M, Trojano M. Safety profile of Tysabri: international risk management plan. Neurol Sci. 2009;30 Suppl 2:S159-62.

28. Ghezzi A, Pozzilli C, Grimaldi LM, Brescia Morra V, Bortolon F, Capra R, et al. Safety and efficacy of Natalizumab in children with multiple sclerosis. Neurology. 2010;75:912-7.

29. Trollet C, Athanasopoulos T, Popplewell L, Malerba A, Dickson G. Gene therapy for muscular dystrophy: current progress and future prospects. Expert Opin Biol Ther. 2009:9:849-66.

30. Mendell JR, Campbell K, Rodino-Klapac L, Sahenk Z, Shilling C, Lewis S, et al. Dystrophin immunity in Duchenne's muscular dystrophy. N Engl J Med. 2010;3(63):1429-37.

31. Hoffman EP, Bronson A, Levin AA, Takeda S, Yokota T, Baudy AR, et al. Restoring dystrophin expression in Duchenne muscular dystrophy muscle progress in exon skipping and stop codon read through. Am J Pathol. 2011;179(1):12-22.

\section{Submit your next manuscript to BioMed Central and take full advantage of:}

- Convenient online submission

- Thorough peer review

- No space constraints or color figure charges

- Immediate publication on acceptance

- Inclusion in PubMed, CAS, Scopus and Google Scholar

- Research which is freely available for redistribution 